\title{
Pengaruh Job Embeddedness, Organizational Commitment, dan Self- Efficacy Terhadap Turnover Intention Karyawan Pada PT. PLN (Persero) UP3 Yogyakarta
}

\author{
Sapfa Rista Monika \\ Universitas Ahmad Dahlan Yogyakarta \\ Ema Nurmaya \\ Universitas Ahmad Dahlan Yogyakarta \\ Email: sapfa1700011286@webmail.uad.ac.id
}

\begin{abstract}
Abstrak
Penelitian ini menyelidiki hubungan antara job embeddedness, organizational commitment, self-efficacy, dan turnover intention. Secara spesifik, hipotesis penelitian ini adalah: 1) Job embeddedness berpengaruh negatif dan signifikan terhadap turnover intention karyawan; 2) Organizational commitment berpengaruh negatif dan signifikan terhadap turnover intention karyawan; 3) Self-efficacy berpengaruh negatif dan signifikan terhadap turnover intention karyawan. Dalam menguji hipotesis, digunakan teknik Regresi Linier Berganda dengan bantuan SPSS 25 untuk menganalisis 66 data yang dikumpulkan dari PT. PLN (Persero) UP3 Yogyakarta. Hasil penelitian ini menunjukkan bahwa job embeddedness berpengaruh negatif dan signifikan terhadap turnover intention karyawan; organizational commitment berpengaruh negatif dan signifikan terhadap turnover intention karyawan; serta self-efficacy tidak berpengaruh negatif dan signifikan terhadap turnover intention karyawan. Kontribusi penelitian memberi manajer resep untuk mengurangi turnover intention dengan meningkatkan job embeddedness dan organizational commitment. Berkenaan dengan kontribusi teoritis, penelitian ini memberikan pemahaman yang lebih baik mengenai masalah turnover intention.
\end{abstract}

Kata Kunci: Job Embeddedness, Organizational Commitment, Self-Efficacy, Turnover Intention.

\section{Pendahuluan}

Perusahaan memerlukan sumber daya manusia untuk mencapai tujuan organisasi. (Dessler 2017: 3) mengemukakan bahwa organisasi berisikan orang-orang dengan peran yang diberikan secara formal untuk bekerja bersama dalam mencapai tujuan organisasi tersebut. Manajer juga harus meningkatkan efektivitas organisasi karena meningkatnya persaingan di antara organisasi (Nurmaya 2020). Oleh karena itu, sumber daya manusia merupakan komponen terpenting untuk keberlangsungan aktivitas organisasi dalam mencapai tujuan secara efektif dan efisien. Sumber daya manusia juga dibutuhkan sebagai agen untuk meningkatkan prospek perusahaan di masa yang akan datang agar mampu bersaing dengan perusahaan lain. Sumber daya manusia yang baik yaitu sumber daya manusia yang mampu memberikan dampak positif dan kinerja yang berkualitas. Baik dampak positif secara profit (hasil) maupun dampak positif di tengah keberlangsungan ketika mencapai profit yaitu menitikberatkan pada proses (perilaku organisasi) dalam mencapai tujuan organisasi. 


\section{Sapfa Rista Monika, Ema Nurmaya}

Menurut (Heritage et al. 2016), "Pergantian karyawan merusak organisasi". Hal tersebut berarti bahwa turnover intention merupakan salah satu isu penting yang harus dihindari.

Turnover intention bukan tindakan keluar yang sesungguhnya, melainkan niat yang mendorong karyawan untuk keluar dari organisasi (Puangyoykeaw \& Nishide 2015). Turnover intention menyebabkan seseorang keluar dari pekerjaannya yang mengakibatkan perusahaan kehilangan tenaga kerja kompeten dan handal sehingga keberlangsungan aktivitas organisasi menjadi tidak stabil. Dampak lain yang akan dialami yaitu perusahaan harus menutupi kekurangan tenaga kerja dan biaya yang dikeluarkan untuk merekrut karyawan baru relatif besar. Berdasarkan hal tersebut, perusahaan harus turut andil dalam keberlangsungan organisasi. Karena meningkatnya persaingan antar organisasi saat ini, manajer didorong untuk menaikkan taraf efektivitas organisasi (Nuzula \& Nurmaya 2020). Oleh karena itu, perusahaan harus memastikan bahwa tingkat turnover intention karyawan, rendah.

Kesadaran bahwa turnover intention berdampak buruk bagi organisasi, menuntut perusahaan untuk menemukan faktor yang menyebabkan penurunan niat tersebut. (Kreitner \& Kinicki 2014: 165) mengemukakan bahwa komitmen organisasi menggambarkan sejauh mana seseorang mengenali organisasi dan terikat pada tujuan-tujuan di dalamnya. Oleh karena itu, keinginan untuk menarik diri dari perusahaan dapat dipicu oleh rendahnya komitmen karyawan terhadap organisasi, sehingga menyebabkan kurangnya rasa keterikatan karyawan. Selain itu, terdapat faktor kepribadian. (Robbins \& Judge 2017: 97) mengemukakan bahwa orang yang memiliki pekerjaan sesuai dengan kepribadian, semestinya lebih puas dan menurunkan risiko pengunduran diri daripada orang-orang yang memiliki pekerjaan tidak sesuai dengan kepribadiannya. Berdasarkan hal tersebut, perusahaan perlu memperhatikan kesesuaian kepribadian karyawan dengan pekerjaan yang akan diemban (personality job fit). (Rukmana 2019) menyatakan bahwa job embeddedness atau keterikatan kerja adalah faktor yang dipertimbangkan karyawan dalam mengambil keputusan untuk tinggal di dalam Usaha Mikro Kecil Menengah atau meninggalkan Usaha Mikro Kecil Menengahnya.

Job embeddedness adalah susunan berisi gambaran mengenai bagaimana karyawan bekerja hingga dapat terlibat dengan pekerjaannya, yang menyebabkan niat untuk keluar dari pekerjaan menjadi berkurang (Heritage et al. 2016). Mereka akan merasa bertanggung jawab dalam menyelesaikan tugas-tugas yang diberi secara formal. Baik tugas jangka pendek berupa tugas harian, maupun tugas jangka panjang di mana turut andil dalam mencapai tujuan organisasi. (Spector 2000) dalam (Yusuf \& Syarif 2018: 29) mengemukakan bahwa komitmen organisasi yaitu sejauh mana individu merasa terlibat atau dilibatkan dengan organisasi tempat ia bekerja dan tidak ingin meninggalkan organisasi tersebut. Seseorang yang berkomitmen akan memiliki ikatan secara emosional bahwa dirinya harus tetap setia pada organisasi beserta tugas-tugas dan tujuan yang ada. Rasa terikat tersebut yang menyebabkan karyawan tidak ingin meninggalkan organisasi karena merasa bahwa organisasi merupakan bagian dari dirinya. Self-efficacy merupakan salah satu faktor yang menentukan sejauh mana karyawan memutuskan untuk bertahan di perusahaan tempat ia bekerja. (Gufron \& Risnawati 2012: 73) mengemukakan bahwa self-efficacy adalah rasa yakin individu tentang kesanggupannya ketika bertugas atau bertindak dalam pencapaian tujuan tertentu. (Rohmawati 2018) mengemukakan bahwa self-efficacy akan menciptakan sikap yang lebih positif terhadap pekerjaan. Individu akan mampu mempertahankan suatu tujuan, menjaga komitmen, dan mengurangi keinginan untuk berpindah kerja.

Tingginya rasa keterikatan, komitmen, dan keyakinan karyawan bahwa ia mampu menyelesaikan tugas dalam pencapaian tujuan organisasi merupakan harapan suatu 
perusahaan. Namun, tidak dapat dipungkiri bahwa banyak faktor lain yang menyebabkan harapan perusahaan tersebut tidak terwujud. Faktor latar belakang sewaktu-waktu dapat menyebabkan menurunnya rasa keterikatan, komitmen, dan keyakinan diri karyawan sehingga menimbulkan keinginan untuk meninggalkan perusahaan. Oleh sebab itu, dapat dikatakan bahwa job embeddedness, organizational commitment, dan self-efficacy merupakan salah satu isu penting dalam suatu perusahaan untuk menghindari turnover intention.

PT. PLN (Persero) UP3 Yogyakarta merupakan salah satu cabang Badan Usaha Milik Negara (BUMN) yang bergerak di bidang ketenagalistrikan, yang terletak di Yogyakarta. Meskipun PT. PLN (Persero) UP3 Yogyakarta termasuk ke salah satu perusahaan yang telah lama beroperasi dengan persepsi tingkat gaji karyawan yang tinggi, tetapi tidak menutup kemungkinan timbulnya niat karyawan untuk keluar dari perusahaan karena ketidakpuasan, rendahnya komitmen, kurangnya keterikatan maupun faktor kepribadian. Kemudian, didukung dengan banyaknya perusahaan lain yang dianggap lebih menjanjikan. Untuk tetap memberikan pelayanan terbaik kepada masyarakat, PT. PLN (Persero) UP3 Yogyakarta tentunya berusaha mempertahankan karyawan yang kompeten dan handal agar tidak adanya turnover intention. Selain itu, belum terdapat judul penelitian serupa pada PT. PLN (Persero) UP3 Yogyakarta. Oleh karena itu, hal ini seharusnya menjadi isu penting dan mendapat perhatian lebih untuk mengantisipasi turnover intention. Berdasarkan alasan tersebut, maka tujuan penelitian ini adalah untuk mendeskripsikan pengaruh job embeddedness, organizational commitment, dan self-efficacy terhadap turnover intention karyawan pada PT. PLN (Persero) UP3 Yogyakarta secara parsial dengan rumusan masalah sebagai berikut:

1. Apakah job embeddedness berpengaruh negatif dan signifikan terhadap turnover intention karyawan?

2. Apakah organizational commitment berpengaruh negatif dan signifikan terhadap turnover intention karyawan?

3. Apakah self-efficacy berpengaruh negatif dan signifikan terhadap turnover intention karyawan?

\section{Landasan Teori dan Pengembangan Hipotesis}

\section{Pengaruh Job Embeddedness Terhadap Turnover Intention Karyawan}

Turnover intention bukan tindakan keluar yang sesungguhnya, melainkan niat yang mendorong karyawan untuk keluar dari organisasi (Puangyoykeaw \& Nishide 2015). (Noe et al. 2011: 20) mengemukakan bahwa karyawan yang tidak puas akan meninggalkan pekerjaan untuk menyelesaikan masalah mereka, baik meninggalkan pekerjaan secara psikologis (menurunnya keterlibatan dan komitmen terhadap organisasi) maupun meninggalkan pekerjaan secara fisik. Sedangkan (Khan et al. 2018) berpendapat bahwa job embeddedness menghubungkan karyawan dengan perusahaan dan pekerjaan mereka, sehingga lebih dekat serta kuat yang mengarah pada kecenderungan karyawan tersebut untuk bertahan di organisasi daripada meninggalkan organisasi. (Clinton et al. 2012) berpendapat bahwa job embeddedness merupakan konsep baru yang menjelaskan mengapa orang bertahan pada pekerjaan mereka. (Nguyen 2015) menyatakan bahwa karakteristik pekerjaan akan memengaruhi job embeddedness, kemudian job embeddedness akan memengaruhi niat karyawan untuk berhenti dari pekerjaan. Job embeddedness dapat digambarkan sebagai jaringan yang mengikat, kemudian jaringan tersebut menyebabkan karyawan terbenam atau terjebak dalam pekerjaan.

Terkait uraian tersebut di atas, seseorang yang merasa terbenam akan cenderung memiliki keterlibatan dan komitmen lebih terhadap perusahaan. Hal ini tentunya akan 
memengaruhi sejauh mana karyawan tersebut ingin tetap tinggal di organisasi, atau meninggalkan organisasi tempat ia bekerja. Semakin tinggi job embeddedness seseorang, maka semakin tinggi pula keterikatan seseorang tersebut terhadap organisasi. Sehingga, menurunkan keinginannya untuk meninggalkan organisasi. Selaras dengan penelitian sebelumnya, (Lee et al. 2004) juga berpendapat bahwa job embeddedness mencerminkan keputusan karyawan untuk menjadi bagian organisasi secara luas dan langsung. Teori telah menyatakan bahwa job embeddedness menunjukkan hubungan atau pengaruh yang luas terhadap retensi karyawan (Mitchell et al. 2001).

Seseorang yang memiliki job embeddedness tinggi akan merasa nyaman dengan lingkungan pekerjaan. Sementara seseorang dengan job embeddedness rendah, akan memicu timbulnya rasa ketidakpuasan dan ketidakpuasan tersebut dapat menjadi salah satu penyebab ia berniat keluar dari pekerjaan. Oleh karena itu, dapat ditarik kesimpulan bahwa job embeddedness dapat memengaruhi keinginan seseorang untuk meninggalkan organisasi tempat ia bekerja. Hal tersebut diperkuat pula oleh penelitian (Khan et al. 2018) dan (Nguyen 2015) yang menyatakan bahwa job embeddedness berpengaruh negatif terhadap turnover intention karyawan. Berdasarkan teori dan bukti penelitian terdahulu di atas, maka dapat dirumuskan hipotesis sebagai berikut:

$\boldsymbol{H}_{1}$ : Job embeddedness berpengaruh negatif dan signifikan terhadap turnover intention karyawan.

\section{Pengaruh Organizational Commitment Terhadap Turnover Intention Karyawan}

Secara teori, selain job embeddedness, organizational commitment juga berpengaruh terhadap turnover intention karyawan. (Yusuf \& Syarif 2018: 32) mengemukakan bahwa komitmen organisasi merupakan sikap kesetiaan karyawan yang dibuktikan dengan cara tetap bertahan di organisasi, membantu organisasi dalam mencapai tujuan, serta tidak berkeinginan meninggalkan organisasi atas dasar apa pun. Sedangkan menurut (Wulandari 2015), komitmen tidak hanya kesetiaan secara pasif terhadap organisasi, tetapi juga melibatkan hubungan aktif.

Terkait uraian tersebut di atas, karyawan yang berkomitmen akan cenderung bertahan. Namun tidak semata-mata bertahan tanpa tujuan, melainkan mendorong karyawan melakukan hal-hal positif seperti membangun ataupun memajukan perusahaan dengan usaha dan upaya. Organizational commitment yang rendah akan menyebabkan keluarnya karyawan dari perusahaan tanpa memikirkan kerugian organisasi. Karyawan lebih mementingkan urusan pribadi, kurangnya rasa memiliki, dan tidak ingin tahu permasalahan yang dihadapi perusahaan karena merasa bahwa organisasi hanya wadah untuk mendapatkan karir tanpa ikatan emosional yang berarti. Karyawan yang berkomitmen terhadap organisai akan setia karena merasa saling membutuhkan, saling melengkapi, dan selalu melakukan yang terbaik demi keberlangsungan organisasi agar tujuan dapat tercapai secara efektif dan efisien. Karyawan juga akan berpikir bahwa apa pun yang terjadi terhadap organisasi merupakan tanggung jawab bersama karena telah berpegang teguh pada komitmen.

Karyawan dengan tingkat komitmen tinggi, masa kerjanya cenderung lebih panjang dibandingkan dengan karyawan yang tingkat komitmennya rendah terhadap perusahaan (Kharismawati \& Dewi 2016). Seseorang yang berkomitmen berarti bahwa ia memihak, serta merasa terikat pada tujuan maupun visi dan misi organisasi. Sehingga, ia akan melibatkan diri, terikat, dan bertanggung jawab dengan faktor yang berkaitan dengan pencapaian tujuan tersebut. Sementara seseorang yang memiliki komitmen organisasi rendah, akan bersikap tidak peduli terhadap nasib, tujuan maupun visi dan misi organisasi. Hal tersebut akan mendorong karyawan untuk bersikap egois, sehingga sewaktu-waktu dapat 
memicu niat untuk keluar dari pekerjan demi keuntungan pribadi. Oleh karena itu, dapat ditarik kesimpulan bahwa organizational commitment dapat memengaruhi keinginan seseorang untuk meninggalkan organisasi tempat ia bekerja. Hal ini diperkuat pula oleh penelitian (Wateknya 2016), dan (Susilo \& Satrya 2019) yang menunjukkan hasil bahwa komitmen organisasi berpengaruh negatif dan signifikan terhadap turnover intention karyawan. Berdasarkan teori dan bukti penelitian terdahulu di atas, maka dapat dirumuskan hipotesis sebagai berikut:

$\boldsymbol{H}_{2}$ : Organizational commitment berpengaruh negatif dan signifikan terhadap turnover intention karyawan.

\section{Pengaruh Self-Efficacy Terhadap Turnover Intention Karyawan}

Selain job embeddedness dan organizational commitment, faktor kepribadian juga berpengaruh terhadaap turnover intention karyawan. Pendapat ini dikemukakan oleh (Robbins \& Judge 2017: 97) yang menyatakan bahwa kepribadian sesuai dengan pekerjaan akan meningkatkan kepuasan dan menurunkan risiko pengunduran diri karyawan. Salah satu elemen kerpibadian yaitu self-efficacy. (Bandura 1997) dalam (Gufron \& Risnawati 2012: 75) mengemukakan bahwa self-efficacy merupakan keyakinan seseorang akan kemampuannya ketika mengerjakan tugas atau tindakan yang diperlukan untuk mencapai hasil tertentu. Sementara (Kreitner \& Kinicki 2014: 125) menyatakan bahwa self-efficacy adalah keyakinan seseorang mengenai kesempatannya untuk berhasil ketika menyelesaikan pekerjaan tertentu. (Robbins \& Judge 2017: 97) mengemukakan bahwa orang-orang yang pekerjaannya selaras (fit) dengan kerpibadian semestinya lebih puas dan meminimalkan risiko pengunduran diri dibandingkan dengan orang-orang yang pekerjaannya tidak selaras dengan kepribadian.

Terkait uraian tersebut di atas, self-efficacy merupakan salah satu elemen kepribadian di mana seseorang berkeyakinan bahwa ia mampu mengerjakan tugas dalam mencapai tujuan. Individu akan bertahan pada suatu kondisi apabila mereka merasa cocok dan kecocokan ini yang nantinya menimbulkan rasa nyaman ketika bekerja. Tingkat self-efficacy tinggi akan menyebabkan seseorang merasa senang dan antusias dengan tugas maupun pekerjaan karena mendapat gambaran mengenai sesuatu yang positif berupa keberhasilan di masa yang akan datang. Ia beranggapan bahwa keberhasilan tersebut pasti akan diraih sesulit apa pun rintangan yang dihadapi. Pemikiran tersebut menyebabkan karyawan cenderung bertahan di organisasi.

Seseorang yang memiliki kepribadian self-efficacy berkeyakinan bahwa ia mampu menyelesaikan tugas-tugas termasuk masalah yang dihadapi dalam organisasi. Hal tersebut mendorong karyawan untuk merasa senang dan tidak terbebani ataupun stres. Mereka akan cenderung memilih untuk tidak meninggalkan organisasi meskipun mengalami kesulitan karena berkeyakinan bahwa sesulit apa pun tugas dan masalah yang dihadapi, akan mampu diselesaikan seiring berjalannya waktu yang harus disertai dengan usaha. Sementara seseorang yang memiliki self-efficacy rendah cenderung pesimis dan tidak percaya diri bahwa mampu menyelesaikan tugas dan rintangan sesulit apa pun yang mereka hadapi. Sehingga, ia berniat untuk meninggalkan organisasi dan berpikir bahwa hal tersebut dapat menyelesaikan masalah. Oleh karena itu, dapat ditarik kesimpulan bahwa self-efficacy dapat memengaruhi keinginan seseorang untuk meninggalkan organisasi tempat ia bekerja. Hal ini diperkuat pula oleh penelitian (Ramadhoani 2020), dan (Saraswati \& Prihatsanti 2017) yang menyatakan bahwa self-efficacy berpengaruh negatif dan signifikan terhadap turnover intention karyawan. Berdasarkan teori dan bukti penelitian terdahulu di atas, maka dapat dirumuskan hipotesis sebagai berikut:

$\boldsymbol{H}_{3}$ : Self-efficacy berpengaruh negatif dan signifikan terhadap turnover intention karyawan. 
Berdasarkan uraian teori dan pengembangan hipotesis, maka model dalam penelitian ini adalah sebagai berikut:

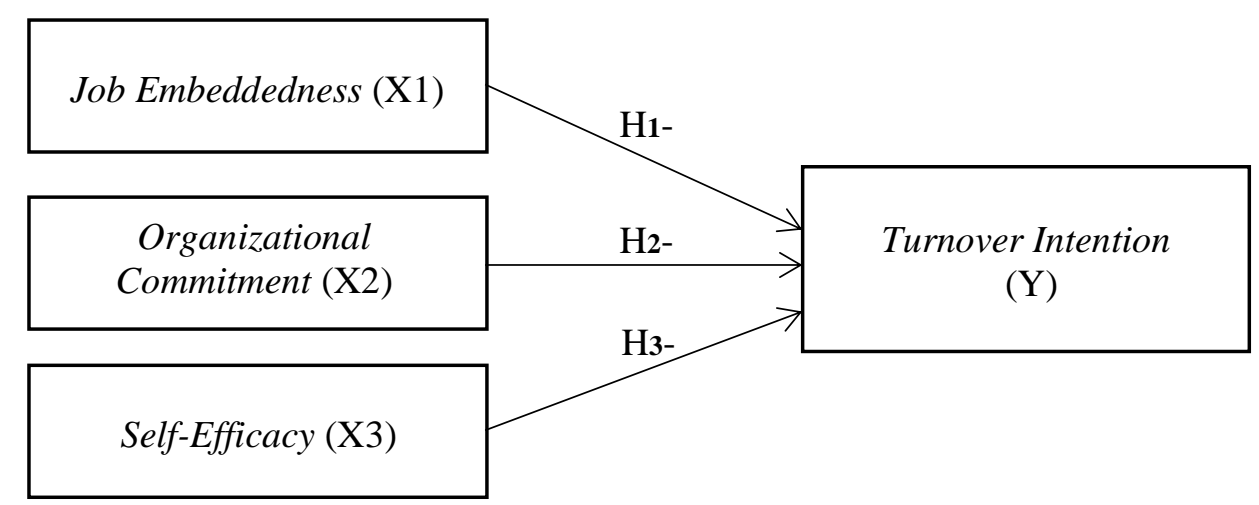

Gambar 1. Model Penelitian

\section{Metode Penelitian}

Populasi dalam penelitian ini adalah seluruh karyawan tetap PT. PLN (Persero) UP3 Yogyakarta yang berjumlah 70 orang. Sampel yang digunakan dalam penelitian ini adalah sampel jenuh. Sampel jenuh yaitu di mana seluruh anggota populasi dijadikan sampel (Sugiyono 2017: 85). Oleh karena itu, sampel dalam penelitian ini berjumlah 70 orang. Penelitian ini menggunakan jenis data primer. Sumber data merupakan para responden yang menjadi sampel dalam penelitian. Pengumpulan data dalam penelitian ini menggunakan kuesioner yang disebar kepada responden berisi pernyataan terkait dengan variabel dependen (turnover intention), serta variabel independen (job embededdness, organizational commitment, dan self-efficacy). Penelitian ini menggunakan kuesioner berskala likert.

Dalam penelitian ini, turnover intention diukur menggunakan alat ukur yang dikembangkan oleh (Mobley et al. 1978). Terdiri dari 3 item pernyataan, contoh: "Saya sering berpikir untuk berhenti dari pekerjaan saya sekarang". Job embeddedness diukur menggunakan alat ukur yang dikembangkan oleh (Crossley et al. 2007). Terdiri dari 7 item pernyataan, contoh: "Saya merasa terikat dengan organisasi ini". Organizational commitment diukur menggunakan alat ukur (versi singkat dari OCQ) yang dikembangkan oleh (Mowdays et al. 1979). Terdiri dari 9 item pernyataan, contoh: "Saya bersedia berupaya melebihi target untuk membantu agar organisasi ini sukses". Self-efficacy diukur menggunakan alat ukur yang dikembangkan oleh (Chen et al. 2001). Terdiri dari 8 item pernyataan, contoh: "Saya akan mampu mencapai sebagian besar tujuan yang telah saya tentukan untuk diri saya sendiri”.

Untuk menguji pengaruh antara variabel independen terhadap variabel dependen digunakan Analisis Regresi Linier Berganda dengan SPSS 25 sebagai alat uji statistiknya. Model Persamaan Regresi Linier Berganda dalam penelitian ini adalah:

$$
\mathrm{Y}=\alpha+\beta 1 . \mathrm{X} 1+\beta 2 . \mathrm{X} 2+\beta 3 . \mathrm{X3}
$$

\footnotetext{
Keterangan:

Y : Turnover Intention

$\alpha \quad$ : Konstanta

$\beta 1, \beta 2, \beta 3$ : Koefisien Determinasi
} 
INOBIS: Jurnal Inovasi Bisnis dan Manajemen Indonesia

Volume 04, Nomor 04, September 2021

Sapfa Rista Monika, Ema Nurmaya

$\begin{array}{ll}\mathrm{X} 1 & : \text { Job Embeddedness } \\ \mathrm{X} 2 & \text { : Organizational Commitment } \\ \mathrm{X} 3 & \text { : Self-Efficacy }\end{array}$

Untuk menguji apakah instrumen dalam penelitian memenuhi syarat alat ukur yang baik, maka digunakan uji validitas dan reliabilitas. Dalam uji instrumen, digunakan sampel sebanyak 30. Sehingga, besarnya $d f$ dapat dihitung $(d f)=30-2=28$. Hasil uji tersebut dianalisis menggunakan Correlation Coefficient Pearson dengan taraf signifikan 10\%. Hasil uji validitas menunjukkan bahwa item pernyataan keseluruhan variabel dinyatakan valid, kecuali item pernyataan keenam dari variabel job embeddedness. Seluruh pernyataan yang valid memiliki r-hitung lebih besar dari r-tabel $(0,306)$. Hal tersebut berarti bahwa item pernyataan yang digunakan untuk mengukur keempat variabel adalah valid, layak digunakan sebagai instrumen penelitian. Sementara hasil uji reliabilitas menunjukkan bahwa intrumen yang digunakan dalam penelitian ini telah memenuhi syarat reliabilitas yang dibuktikan dengan nilai Cronbach's Aplha variabel turnover intention $=0,916$, variabel job embeddedness $=0,870$, variabel organizational commitment $=0,915$, dan variabel selfefficacy $=0,917$ yang berarti lebih besar dari 0,60.

\section{Pembahasan}

Penelitian ini dilakukan pada PT. PLN (Persero) UP3 Yogyakarta. Total kuesioner yang disebar sebanyak 70, sementara kuesioner yang kembali berjumlah 66. Jadi, total responden yaitu sebanyak 66 responden. Komposisi responden berdasarkan jenis kelamin menunjukkan bahwa responden wanita yang lebih dominan yaitu 51,52\% dari total responden. Hal ini berarti bahwa sebagian besar responden pada PT. PLN (Persero) UP3 Yogyakarta adalah berjenis kelamin wanita. Komposisi responden berdasarkan usia menunjukkan bahwa responden berusia 25-35 tahun yang lebih dominan yaitu 34,85\% dari total responden. Komposisi responden berdasarkan pendidikan terakhir menunjukkan bahwa responden berpendidikan SLTA yang lebih dominan yaitu 43,94\% dari total responden. Komposisi responden berdasarkan lama bekerja menunjukkan bahwa responden yang telah bekerja lebih lama dari 10 tahun yang lebih dominan yaitu 62,12\% dari total responden. Komposisi responden berdasarkan status menunjukkan bahwa responden berstatus telah menikah yang lebih dominan yaitu $80,30 \%$ dari total responden. Komposisi responden berdasarkan penghasilan menunjukkan bahwa responden berpenghasilan lebih besar dari 5 juta yang lebih dominan yaitu 77,27\% dari total responden.

\section{Uji Model}

\section{Analisis Regresi Linier Berganda}

Penelitian ini menggunakan uji t. Uji t digunakan untuk mengetahui pengaruh variabel independen (job embeddedness, organizational commitment, dan self-efficacy) terhadap variabel dependen (turnover intention) secara parsial. Apabila nilai signifikan $<0,1$, maka H0 ditolak dan Ha diterima yang berarti ada pengaruh signifikan antara variabel independen terhadap variabel dependen. Apabila nilai signifikan > 0,1, maka H0 diterima dan Ha ditolak yang berarti tidak ada pengaruh signifikan antara variabel independen terhadap variabel dependen. Ada pun hasil uji regresi secara parsial (uji t) adalah sebagai berikut: 
INOBIS: Jurnal Inovasi Bisnis dan Manajemen Indonesia

Volume 04, Nomor 04, September 2021

Sapfa Rista Monika, Ema Nurmaya

Tabel 1. Hasil Analisis Regresi Linier Berganda

Coefficients $^{a}$

\begin{tabular}{|l|r|r|r|r|r|}
\hline \multirow{2}{*}{ Mode1 } & \multicolumn{2}{|c|}{$\begin{array}{c}\text { Unstandardized } \\
\text { Coefficients }\end{array}$} & $\begin{array}{c}\text { Standardized } \\
\text { Coefficients }\end{array}$ & & \\
\cline { 2 - 6 } & \multicolumn{1}{|c|}{$B$} & \multicolumn{1}{|c|}{ Std. } & & \\
& Error & Beta & \multicolumn{1}{c|}{$t$} & \multicolumn{1}{c|}{ Sig. } \\
\hline (Constant) & 4,417 &, 772 & & 5,720 &, 000 \\
(X1) &,- 444 &, 171 &,- 365 & $-2,590$ &, 012 \\
(X2) &,- 436 &, 233 &,- 316 & $-1,875$ &, 065 \\
(X3) &, 163 &, 253 &, 088 &, 642 &, 523 \\
\hline
\end{tabular}

a. Dependent Variable: Turnover Intention (Y)

Sumber: Data diolah, 2020

Berdasarkan hasil tabel 1. tersebut di atas, diketahui bahwa nilai t-hitung job embeddedness sebesar -2,590. Sedangkan nilai signifikan (P. 0,012) lebih kecil dari $\alpha=10 \%(0,1)$. Karena nilai signifikan < 0,1, maka H0 ditolak dan H1 diterima. Dapat disimpulkan bahwa job embeddedness berpengaruh negatif dan signifikan terhadap turnover intention karyawan. Nilai t-hitung oganizational commitment sebesar -1,875. Sedangkan nilai signifikan (P. $0,065)$ lebih kecil dari $\alpha=10 \%(0,1)$. Karena nilai signifikan $<0,1$, maka H0 ditolak dan $\mathrm{H} 2$ diterima. Dapat disimpulkan bahwa organizational commitment berpengaruh negatif dan signifikan terhadap turnover intention karyawan. Nilai t-hitung self-efficacy sebesar 0,642. Sedangkan nilai signifikan (P. 0,523) lebih besar dari $\alpha=10 \%(0,1)$. Karena nilai signifikan $>$ 0,1, maka H0 diterima dan H3 ditolak. Dapat disimpulkan bahwa self-efficacy tidak berpengaruh negatif dan signifikan terhadap turnover intention karyawan.

Berdasarkan hasil koefisien regresi pada tabel 1., maka diperoleh persamaan regresi sebagai berikut:

\section{$Y=4,417-0,444 X 1-0,436 \times 2+0,163 \times 3$}

Dari persamaan regresi tersebut, maka dapat disimpulkan bahwa koefisien regresi turnover intention (Y) sebesar 4,417, merupakan nilai konstanta. Jika nilai job embeddedness (X1), organizational commitment (X2), dan self-efficacy (X3) dianggap 0, maka turnover intention (Y) nilainya sebesar 4,417. Koefisien regresi job embeddedness (X1) sebesar -0,444, menyatakan bahwa setiap kenaikan nilai job embeddedness (X1) dan nilai dari variabel lainnya tetap (konstan), maka turnover intention (Y) akan turun sebesar 0,444 satuan. Koefisien regresi organizational commitment (X2) sebesar -0,436, menyatakan bahwa setiap kenaikan nilai organizational commitment dan nilai dari variabel lainnya tetap (konstan), maka turnover intention (Y) akan turun sebesar 0,436 satuan. Koefisien regresi self-efficacy (X3) sebesar 0,163, menyatakan bahwa setiap kenaikan nilai self-efficacy dan nilai dari variabel lainnya tetap (konstan), maka turnover intention (Y) akan naik sebesar 0,163 satuan.

\section{Koefisien Determinasi (R Square)}

Koefisien determinasi (R Square) digunakan untuk mengukur sejauh mana model mampu menerangkan variasi variabel terikat (dependen). Rentang nilai koefisien determinasi antara nol dan satu (Kuncoro 2013: 246). Semakin kecil nilai koefisien determinasi, maka semakin kecil kemampuan variabel-variabel independen dalam menjelaskan variabel dependen. Semakin besar nilai koefisien determinasi, maka semakin besar pula kemampuan variabel-variabel independen dalam menjelaskan variabel dependen. 
Tabel 2. Hasil Uji Determinasi Model Summary ${ }^{b}$

\begin{tabular}{|l|c|r|r|r|}
\hline Model & $R$ & $R$ Square & $\begin{array}{l}\text { Adjusted } \\
R \text { Square }\end{array}$ & $\begin{array}{c}\text { Std. Error of } \\
\text { the Estimate }\end{array}$ \\
\hline 1 &, $577^{\mathrm{a}}$ &, 333 &, 300 &, 60281 \\
\hline
\end{tabular}

a. Predictors: (Constant), Self-Efficacy, Job

Embeddedness, Organizational Commitment

b. Dependent Variable: Turnover Intention (Y)

Sumber: Data diolah, 2020

Berdasarkan hasil tabel 2. tersebut di atas, diperoleh nilai R Square sebesar 0,333 (33,3\%). Hal tersebut berarti bahwa sebesar 33,3\% turnover intention karyawan pada PT. PLN (Persero) UP3 Yogyakarta dijelaskan oleh job embeddedness, organizational commitment, dan self-efficacy. Sedangkan $66,7 \%$ sisanya, dijelaskan oleh variabel lain yang tidak terdapat dalam penelitian.

\section{Hasil Uji Hipotesis}

Hasil pengujian hipotesis pertama menunjukkan bahwa job embeddedness berpengaruh negatif dan signifikan terhadap turnover intention karyawan. Hal ini berarti bahwa tingginya job embeddedness mampu menurunkan niat karyawan untuk meninggalkan organisasi. Job embeddedness dapat terbentuk apabila adanya hubungan antar karyawan dalam organisasi maupun komunitas. Karyawan akan menelaah apakah ia merasa nyaman dengan organisasi, atau merasa sesuai dengan komunitas yang terbentuk di luar urusan organisasi. Pada akhirnya, karyawan akan berpikir pengorbanan apa yang akan ditanggung apabila memutuskan untuk meninggalkan keduanya (organisasi dan komunitas). Tentunya karyawan akan kehilangan berbagai macam keuntungan seperti kolega, teman, proyek, tunjangan, dan bonus. Selain itu, meninggalkan komunitas juga bukan sesuatu hal yang mudah. Karyawan akan kehilangan kenyamanan, hubungan yang menyenangkan, ataupun status di mana ia dapat dihargai dan disenangi serta hal tersebut belum tentu ia dapatkan di tempat lain. Oleh karena itu, dapat disimpulkan bahwa semakin karyawan tertaut dan cocok dengan oganisasi, maka karyawan akan semakin sulit menerima pengorbanan apabila memutuskan untuk meninggalkan organisasi. Hasil penelitian ini sejalan dengan (Khan et al. 2018) dan (Nguyen 2015) yang menyatakan bahwa job embeddedness berpengaruh negatif terhadap turnover intention karyawan.

Hasil pengujian hipotesis kedua menunjukkan bahwa organizational commitment berpengaruh negatif dan signifikan terhadap turnover intention karyawan. Hal ini berarti bahwa organizational commitment mampu menurunkan niat karyawan untuk meninggalkan organisasi. Organizational commitment adalah keterlibatan karyawan atau individu dengan tugas, visi dan misi organisasi. Seseorang yang berkomitmen akan berpihak pada organisasi dan selalu melakukan hal-hal positif yang dapat meningkatkan keberhasilan organisasi di masa sekarang dan di masa yang akan datang. Seseorang yang selalu melakukan hal-hal positif untuk memajukan perusahaan akan cenderung tidak berniat meninggalkan organisasi karena berdampak merugikan organisasi. Hasil penelitian ini sejalan dengan penelitian (Wateknya 2016) dan (Susilo \& Satrya 2019) yang menyatakan bahwa organizational commitment berpengaruh negatif dan signifikan terhadap turnover intention karyawan. 
Hasil pengujian hipotesis ketiga menunjukkan bahwa self-efficacy tidak berpengaruh negatif dan signifikan terhadap turnover intention karyawan. Hal ini berarti bahwa tingginya self-efficacy tidak mampu menurunkan niat karyawan untuk meninggalkan organisasi. Ketika seseorang memiliki keyakinan yang tinggi bahwa ia dapat mengerjakan tugas dan menghadapi berbagai macam rintangan, karyawan akan cenderung bersemangat dalam bekerja dan tidak mengalami stres yang memicu turnover intention. Penelitian ini menunjukkan bahwa tidak ada pengaruh negatif dan signifikan. Hasil penelitian ini tidak sejalan dengan hasil penelitian (Ramadhoani 2020) dan (Saraswati \& Prihatsanti 2017) yang menyatakan bahwa self-efficacy berpengaruh negatif dan signifikan terhadap turnover intention karyawan.

Arah dalam penelitian ini positif, sejalan dengan hasil penelitian yang dilakukan oleh (Rohmawati 2018). Artinya, self-efficacy yang tinggi dapat meningkatkan turnover intention dari waktu ke waktu. Meskipun seseorang dengan kepribadian self-efficacy yakin bahwa dirinya mampu menyelesaikan tugas dan hambatan yang dihadapi perusahaan, tidak sematamata menyebabkan karyawan tersebut tetap bertahan di perusahaan tanpa ada niat untuk keluar dari organisasi. Seseorang dengan kepribadian self-efficacy terkadang percaya bahwa ia juga dapat berhasil dalam organisasi baru jika memutuskan untuk meninggalkan organisasi tempat bekerja sebelumnya, meskipun harus merelakan keuntungan dan menghadapi berbagai macam kerugian. Karyawan akan mencari perusahaan yang lebih baik dari sebelumnya dan percaya bahwa suatu hari nanti ia pasti akan berhasil.

\section{Kesimpulan}

Berdasarkan hasil analisis data dan pembahasan yang telah diuraikan dalam penelitian ini, maka dapat disimpulkan bahwa: Pertama, job embeddedness berpengaruh negatif dan signifikan terhadap turnover intention karyawan. Kedua, organizational commitment berpengaruh negatif dan signifikan terhadap turnover intention karyawan. Ketiga, selfefficacy tidak berpengaruh negatif dan signifikan terhadap turnover intention karyawan.

\section{Daftar Pustaka}

Chen, G., Gully, S. M., \& Eden , D. (2001, January). Validation of a New General SelfEfficacy Scale. Organizational Research Methods, 4(1), 62-83.

Clinton, M., Knight, T., \& Guest, D. E. (2012). Job Embeddedness: A New Attitudinal Measure. International Journal of Selection and Assesment, 20(1), 111-117.

Crossley, C. D., Jex, S. M., Bennet, R. J., \& Burnfield, J. L. (20017). Development of a Global Measure of Job Embeddedness and Integration Into a Traditional Model of Voluntary Turnover. Journal of Apllied Psychology, 92(4), 1031-1042.

Dessler, G. (2017). Manajemen Sumber Daya Manusia. Jakarta: Salemba Empat.

Gufron, M. N., \& S, R. R. (2012). Teori-Teori Psikologi. Yogyakarta: Ar-Ruzz Media.

Heritage, B., Gilbert, J. M., \& Roberts, L. D. (2016). Job Embeddedness Demonstrates Incremental Validity When Predicting Turnover Intention for Australian University Employee. Frontiers in Psychology, 7, 1-12.

Khan, M., Aziz, S., Afsar, B., \& Latif, A. (2018). The Effect of Job Embeddedness on Turnover Intentions, Work Engagement, and Job Performance. Journal of Tourism \& Hospitality, 7(3), 1-9. 
Kharismawati, D. A., \& Dewi, I. G. (2016). Pengaruh Komitmen Organisasional, Dukungan Sosial, dan Iklim Etika Terhadap Turnover Intention. E-Jurnal Manajemen Unud, 5(2), 1368-1398.

Kreitner , R., \& Kinicki, A. (2014). Perilaku Organisasi. Jakarta: Salemba 4.

Kuncoro , M. (2013). Metode Riset untuk Bisnis dan Ekonomi. Jakarta: Erlangga.

Lee, T., Mitchell, T., Sablynski, C. J., \& Burton, J. P. (2004). The Effect of Job Embeddedness on Organization Citizenship, Job Performance, Volitional Absences, and Voluntary Turnover. The Academy of Management Journal, 47(5), 711-722.

Mitchell, T. R., Holtom, B. C., Lee, T. W., Sablynski, C. J., \& Erez, M. (2001). Why People Stay: Using Job Embeddedness to Predict Voluntary Turnover. Academy of Management Journal, 44(6), 1102-1121.

Mobley, W. H., Horner, S. O., \& Hollingsworth, A. T. (1978). An Evaluation of Precursors of Hospital Employee Turnover. Journal of Apllied Psychology, 63(4), 408-414.

Mowdays , R. T., \& Steers, R. M. (1979). The Measurement of Organizational Commitment. Journal of Vocational Behavior, 14(2), 224-247.

Nguyen, V. Q. (2015). Job Characteristics, Job Embeddedness, and Turnover Intention: The Case of Vietnam. Journal of International \& Interdiciplinary Business Research, 2(1), 98-109.

Noe, R. A., Hollenbeck, J. R., Gerhart, B., \& Wright, P. M. (2011). Manajemen Sumber Daya Manusia: Mencapai Keunggulan Bersaing. Jakarta: Salemba Empat.

Nurmaya, E. (2020). Memprediksi Penyimpangan Interpersonal dari Keadilan Prosedural dan Keadilan Informasional. Jurnal Fokus, 10(2), 269-280.

Nuzula, I. F., \& Nurmaya, E. (2020). The Influence of Distributive Justice, Job Satisfaction, and Affective Commitment to Organizational Citizenship Behavior. Revista Produção E Desenvolvimento, 6, 1-19.

PT. PLN (Persero). PLN (Persero) Profil. Diakses dari https://portal.,pln.co.id/ provides PT pada tanggal 16 November 2020.

Puangyoykeaw, K., \& Nishide, Y. (2015). Organizational Commitment and Turnover Intention in Low-Skilled Immigrant Workers in Thailand: An Empirical Assesment of Need Satisfaction, Job Satisfaction, and Overall Life Satisfaction Factors. International Journal of Business and Management, 10(5), 98-112.

Ramadhoani, V. P. (2020). Pengaruh Lingkungan Kerja, Self Efficacy, Work-Family Conflict, dan Employee Engagement Terhadap Turnover Intention Pegawai Kantor Badan Sar Nasional Mataram. Journal FEB Unmul, 22(1), 82-94.

Robbins, S. P., \& Judge, T. A. (2017). Perilaku Organisasi. Jakarta: Salemba Empat.

Rohmawati, E. (2018). Analisis Pengaruh Efikasi Diri Terhadap Keinginan Berpindah Kerja dengan Kepuasan Kerja Sebagai Variabel Pemediasi (Survei pada Auditor Independen di Indonesia). Jurnal Akuntansi dan Manajemen, 15(1), 36-60.

Rukmana, T. C. (2019). Pengaruh Kompensasi dan Job Embeddedness Terhadap Turnover Intention yang Dimediasi Oleh Kepuasan Kerja Pada Karyawan Part Time UMKM Chockles Es Cokelat di Cabang Yogyakarta. Skripsi. Yogyakarta: Universitas Pembangunan Nasional "Veteran".

S, N. K., \& Prihatsanti, U. (2017). Hubungan Antara Self-Efficacy dengan Intensi Turnover Pada Karyawan PT. Indonesia Taroko Textile Purwakarta. Jurnal Empati, 6(1), 307311.

Sugiyono. (2017). Metode Penelitian Kuantitatif, Kualitatif, dan R\&D. Bandung: Alfabeta. 
Susilo, J., \& Satrya, I. G. (2019). Pengaruh Kepuasan Kerja Terhadap Turnover Intention yang Dimediasi oleh Komitmen Organisasinal Karyawan Kontrak. E-Jurnal Manajemen, 8(6), 3700-3729.

Wateknya, Y. (2016). Pengaruh Komitmen Organisasi dan Kepuasan Kerja Terhadap Turnover Intention (Studi Kasus Pada Karyawan PT. Kharisma Rotan Mandiri). SKripsi. Yogyakarta: Universitas Negeri Yogyakarta.

Wulandari, P. (2015). Pengaruh Kepuasan Kerja dan Komitmen Organisasi Terhadap Organizational Citizenship Behavior Perawat Rumah Sakit Islam Yogyakarta. Skripsi. Yogyakarta: Universitas Negeri Yogyakarta.

Yusuf, R. M., \& Syarif, D. (2018). Komitmen Organisasi: Definisi, Dipengaruhi, \& Mempengaruhi. Makassar: Nas Media Pustaka. 